ISBN $978-93-5137-179-3$

Concept of Dhatusarata in Brihatsamhita of

\title{
Varahamihir: A Review
}

\section{Kiran R. Pabitwar*1 ${ }^{\text {, Pramod Garje }}{ }^{2}$}

1. Associate Professor, Department of KriyaSharir, Government Ayurved College, Nanded

2. Professor, Rognidan Dept. Shri Ayurved College, Nagpur.

*Corresponding Author: 9422873676 Email: pabitwarkiran@ gmail.com

\section{Abstract:}

Dhatusaratvaparikshan is one of the basic principles comprehend in DashvidhaAaturpariksha (tenfold examination). It is one of the way by which we can assess stoutness of Dhatu of an individual. As far as Ayurvedic literature is concerned we can see ready references regarding description of Dhatusarta. Charaka has described peculiarities of sara in detail whereas Susruta has described it a pattern of one line for each sara. Vagbhata has described Sara in scattered way in which no particular sara has been mentioned we have to assume it in elsewhere description such as signs of Dirghaushywaan Purusha (signs of long life). Kashypa Samhita gives us little but important clue regarding clinical importance of sara; unfortunately after having description regarding Rasasara and Raktasara there is a discontinuation and further description is unavailable. For rejuvenation of own science it is our duty to have a review in different streams in order to find out new references and information. Brihatsamhita is an informative compendium composed by Aacharya Varahamihir which is mainly based on description of Astrology and Vastushastra (Architecture). In $68^{\text {th }}$ chapter of this compendium Dhatusarta has been described. Though the topic is in a concise form; it gives certain ideas regarding sarata and some additional peculiarities are also available which will help to person from ancient science stream. This article has been enlightened on typical and unique features described by Varahamihira about Dhatusarata.

KEYWORD: Dhatusarata, Dashvidha Aatur Parikshana 


\section{INTRODUTION:}

Assessment of Dhatusartva is one of an important tool for having an idea of individual's Dhatubala (stamina). Sara means an excellent genuine part of dhatu which indicates us the purity and efficiency of dhatu. Doshas always try to defeat or attack on Dhatu; there is always a combat between dosha and dhatu. Therefore an ideal life style and determined approach is advised in order to overcome disease like situation. In Vimanasthana chapter 8 of Charaka samhita there is a detail description available regarding Dhatusarava manifestations. Prakruti gives us an idea regarding Doshabala of a person. It provides us what care should be taken in order to maintain health? Certain Physical and Psychological manifestations give an idea to Ayurvedic Physician. On the basis he has certain assumptions and ideas about dealing with individual's health. A detail and elaborative literature is available regarding Prakruti in various compendiums. As far as description of Sara is considered very less and concise information is available. To replenish our own science it is necessary to have a review on contemporary literature of allied stream. Brihat Samhita is the compendium in which basic theme regarding Jyotish shastra (Uranology) and Wastushastra (Architectural science) is discussed severally. In chapter 68 of the same concept of Dhatusartva manifestations are available. It is necessary to have a review on the same; this article will definitely give some idea and will guide Ayurved faculties regarding Dhatusartva.

\section{Aim and objectives:}

- To have a detail review on manifestations of Dhatusara in Brihat Samhita.

- To discuss and compare critically on typical characters of Sara in Brihat Samhita with available reference.

\section{Material and method:}

As this is a review type of article; references regarding basic of Dhatusarta in major compendium and Brihat Samhita have been studied from different texts.

\section{Review:}

In chapter 68 mentioned as Purushlakshana adhyaya there is a description regarding Dhatusarta is as follows:

There are different seven types of Sara as Meda, Majja, Twag, Asthi, Shukra, Rudhira, Mansa ${ }^{[1]}$

- सप्तभवन्तीच सारामेदोमज्जात्वगस्थिशुक्क्राणि| रुधिरंमांसचेती प्राणभृतां तत्समाफलम॥ तालुओष्ठादंतपालीजिव्हानेत्रान्तपायुकरचरणे: | रक्ते तू रक्तसारा बहुसुख वनितार्थपुत्रयुता: ॥ स्निम्ध त्वक्का धनिनो मृदुभी : सुभगाविचक्षणा: तनुभि:।

मज्जा मेद सारा सुशरीरापुत्रवित्तयुता: ॥ स्थुलास्थी:अस्थिसारोबलवानविद्यांतगःसुरुपस्च| बहुगुरुशुक्राः सुभगा विद्वांसो रुपवन्त्स्च| उपचितदेहो विद्वान धनी सुरुपस्च मांससारो यः| संघात इति च सुश्लिष्टसंधीहा सुखभूजो जेया||96-100.

- Person who have dominance of Raktasara; have organs like Talu ( palate), Oshta (lips), Danta (teeth) 
,Pali (ear lobule), Jivha (tongue), Netrant (corners of eyes), Payu (anus), Kar (palms) Charan (soles) which are Rakte (red) in color. Such person bestowed with rich qualities as bahusukha (comfort and luxury), vanita (good wife) arth (money) and putra (progeny).

- Twak sara person is having physical feature as Snigdhatwacha (unctuousness of skin), Mrudu twacha (delicate, soft skin), Тапu (thin skin) and has bounty of Dhana (richness) and Vichakshana (curious mind).

- Majja and Meda sara persons are bestowed with qualities like Susharira (handsome) and Putravittayuta (accomplished with wealth and strong progeny).

- Asthisara people possess morphological character as Sthula asthi (strong and large bones), Balawan (strong, virile) and Surupasch (handsome); enriched with quality like Vidyawaan (sage).

- Person of Shukrasara possess Physical qualities like Bahugurushukra (large quantity of semen viscous in appearance), and Rupvanta (handsome). They are bestowed with Bhagya and Vidya (luck and knowledge).

- Mansasara person possess Upchitdeha and Surupta (strong built and handsome appearance). They are bestowed with qualities like Vidwaan and Dhani (knowledge and wealth). They also possess a proportionate and dense musculature of joints which is termed as Suslishtasandhi; such person enjoys life with satisfaction.

\section{Discussion:}

\section{Description of Sara in Ayurved Texts:}

- Dhatusarata examination is necessary to assess the power of Dhatu and its constitution. Sara word is derived from SruSthire root which shows steady, stabilized, fixed part of Dhatu part. Dhatu are categorised in different classes as Shuddha, Vishuddha, AtyathaShuddha and Vishuddhtara. Shuddha means polished or clean Dhatu which is concerned with routine functions of Dhatu. Vishuddha are concerned with Bala and Varna, (strength and complexion). AtyarthaShuddha are related to perception of Indriya, (sense organ), for ex. Sparsha (touch sense) can be understood by Rakta. Fourth is VishudhtaraDhatu which is destined to do all type of functions which are mentioned in signs of Dhatusaratva. This means that all the particular morphological and psychological manifestations are concerned with Saravaan Dhatu.

- If we go through the available literature regarding description of Sara; it is observed that only Charaka has described it in detail whereas as the generation proceeds a scanty and little discussion is available in other major compendium. ${ }^{[2]}$

- In Laghutrayee and other related Ayurvedic texts not a little shade is available about the Sara. Kashyapa has described Sara; unfortunately it is in sparse form and as soon as description of Twak sara and a line on Rakta sara is over; continuity breaks.

- Though the Kashyapa description is very less; it gives a clue regarding clinical and immunological importance 
of Sara. Twak sara persons are resistant to skin diseases and if they occurs they will recover soon and fast wound healing will happen in Twak sara persons; all these feature were mentioned by words Twakraorahito, Sadykshatprarohan. ${ }^{[3]}$

- Susruta has described each Sara in line to line stanza and in a concise form with some peculiar charecters like Achidragatra (absence of slits in palm and sole), Mahnetram (bigger eye size) etc. which gives some additional inputs.

\section{Description of Sara in Brihat Samhita:}

- Brihat Samhita is a contemporary compendium in which Astrology; Architecture and health issues of horse and elephant were discussed.

- There is a discussion available regarding health and things concerned with routine human life; so we can postulate that it is an allied compendium to Ayurved.

- In chapter 68 Purushlakshana Adhyaya description regarding Sara is available with a typical peculiarities can be shown in following way-

a. Only seven type of Sara were described; Satva sara and Satva sara information is unavailable.

b. Chronology regarding existence of Dhatu name is no maintained instead of Rasa, rakta mansa, meda......meda, majja, twak, asthi, shukra, rakta, mansa, sara has been described

c. Though above type of discordance is seen; information is very helpful to academicians. d. Rasa sara is denoted by the term Twag sara which indicates similarity of theory that reflection of Rasa dhatu can be seen on Twak. There is similarity of description with Charaka as Vidyawantah and Buddhi is labeled Vichakshana term.

e. Rakta sara is denoted by synonym Rudhira sara. It matches with Charaka with certain exception that corners of eyes are red instead of whole eye; Рауи organ (anus) is additional inclusion in red organ list told by Charaka. Other major input is that joyful life, caring wife, wealth and plenty of progeny are the additional points mentioned which will help in actual assessment of Sara.

f. Mansa sara includes additional physic sign like Surupasch and Vidwaan (handsomeness and intellectuality) and common included peculiarities are Upchitdeha and Dhani (strong musculature, richness).

g. Meda and Majja sara have common features like Susharira and Putravittayuta. If we analyze these properties instead of Susharira Charaka and Susrurta denoted such persons as Brihat sharira. Having more number of progeny with parental quality is mentioned in case of Majja sara as Apatyabhaja; regarding Meda sara it not mentioned.

h. In case of Asthisara; Vidyantaga and Surupsch (knowledge and handsomeness) are two new inclusions which are not in Established compendium. 
i. Shukrasara person possess manifestations like Bhau guru shukra (quantitative amount of semen with viscous appearance). They are bestowed with fortune, intellectuality and handsome look.

\section{Conclusion:}

If we go through the description of Brihat Samhita regarding Dhatu sarta we can find that though the description is less it is additional information. Certain comprehensive words are used which gives an idea of sara; for example.

a) Sthulasthi asthisaro word indicates that all the bones are larger and dense.

b) Upchit Deho term is widely indicative of all body parts where flesh is covered.

Certain additional characters can give us an idea in case of Sara examination in which any additional point rather than Charaka or Susruta description is found. Such words are raktavarni, pali,netrant, payu, vanitasukha, in case of Raktasara. Susharia term in case of Meda sara is an exceptional addition. Vidyawaan quality of Asthisara is an addition. Bahuguru shukra is a qualitative sign regarding semen is crux inclusion.

On the basis of above discussion we can conclude that the comprehensive points and additional points raised in Brihat samhita definitely helps an Ayurvedic scholar to analyze Sara with all respects.

\section{Reference:}

1. Pandit Achutanand Jha, [1 BrihatSamhita[2] of Varahamihira[3] Hindi [4] vol- [5]revised ed [6]PurushaLakshanaAhdhya68/96-

100[7].ChoukhambaVidyabhavan[8]V aranasi [9]2014[10]pp435- 436.

2. Pan.KashinathShastri,DrGorakhnathCh aturvedied [1]CharakSamhita[2]of Agneevesha[3] Hindi [4] vol 1 [5]seventeenth ed [6]VimanasthanaRogabhishagjitiyaAh dhya 08/102 [7].ChoukhambaBharati
Academy
[8]Varanasi
[9]1993 [10]pp751

3. PanditHemarajaSharma,ShriSatyapalBh ishagacharyaed[1]KashyapaSamhita[2] of Vruddhajivaka[3] Hindi [4] vol[5]fourth ed

[6]SutrasthanaLakshanaAhdhya 28/29

[7].ChoukhambaSanskrit Sansthan [8]Varanasi [9]1988 [10]pp54-55.

\section{Cite this article:}

Concept of Dhatusarata in Brihatsamhita of Varahamihir: A Review Kiran R. Pabitwar, Pramod Garje

Ayurlog: National Journal of Research in Ayurved $S_{\text {cience-2017; 6(1): 1-5 }}$ 